\title{
The Association of Religious Affiliation with Overweight/Obesity among South Asians: The Mediators of Atherosclerosis in South Asians Living in America (MASALA) Study
}

\author{
Nazleen H. Bharmal ${ }^{a}$, William J. McCarthy ${ }^{b}$, Meghana D. Gadgil ${ }^{c}$, Namratha R. Kandulad, \\ and Alka M. Kanaya
}

aRAND Corporation 1200 S. Hayes Street Arlington, VA 22202-5050, USA nbharmal@rand.org bUCLA Fielding School of Public Health Department Cancer Prevention \& Control Res/FSPH \& JCCC BOX 956900, A2-125 CHS Los Angeles, CA 90095-6900, USA wmccarth@ucla.edu 'UCSF Division of General Internal Medicine 1545 Divisadero Street San Francisco, CA 94115, USA meghana.gadgil@ucsf.edu dNorthwestern University Feinberg School of Medicine, Department of General Internal Medicine 750 N Lake Shore Drive, 10 $0^{\text {th }}$ Floor Chicago, IL 60611, USA nkandula@nmff.org

\begin{abstract}
Background-Religiosity has been associated with greater body weight. Less is known about South Asian religions and associations with weight.

Methods-Cross-sectional analysis of the MASALA study ( $\mathrm{n}=906$ ). We examined associations between religious affiliation and overweight/obesity after controlling for age, sex, years lived in the U.S., marital status, education, insurance status, health status, and smoking. We determined whether traditional cultural beliefs, physical activity, and dietary pattern mediated this association.

Results-The mean BMI was $26 \mathrm{~kg} / \mathrm{m}^{2}$. Religious affiliation was associated with overweight/ obesity for Hindus (OR 2.12; 95\% CI: 1.16, 3.89), Sikhs (OR 4.23; 95\% CI: 1.72, 10.38), and Muslims (OR 2.79; 95\% CI: 1.14, 6.80) compared with no religious affiliation. Traditional cultural beliefs (7\%), dietary pattern (1\%) and physical activity (1\%) mediated $9 \%$ of the relationship.

Conclusions-Interventions designed to promote healthy lifestyle changes to reduce the burden of overweight/obesity among South Asians need to be culturally and religiously tailored.
\end{abstract}

\section{Keywords}

overweight; obesity; religious affiliation; South Asian

\footnotetext{
Corresponding Author: Alka M. Kanaya, MD, UCSF Division of General Internal Medicine, 1545 Divisadero Street, Suite 311, San Francisco, CA 94115, USA, alka.kanaya@ucsf.edu, Phone: (415) 353-7919, FAX: (415) 514-8886.

Compliance with Ethical Standards: Conflict of Interest: The authors declare that they have no conflict of interest.

Research involving human participants: Informed consent was obtained from all individual participants included in the study.
} 


\section{BACKGROUND}

South Asians are one of the fastest growing ethnic groups in the U.S. and over $90 \%$ are foreign-born $(1,2)$. Compared to other racial/ethnic groups, South Asians have greater risk of obesity-related conditions, such as diabetes mellitus and coronary heart disease (3-6). Physical inactivity, diets low in fruits and vegetables, and central adiposity are believed to contribute to this disparity $(3,7-11)$.

Similar to other immigrant groups, South Asians may be involved in cultural and religious activities that revolve around traditional norms, such as participation in customary religious services (12-17). Religiosity among diverse racial/ethnic groups, such as Whites, African Americans, Hispanics, and Chinese Americans, has been associated with greater body weight or overweight/obesity (18-20). In a prior study, religiosity was positively associated with being overweight/obese among South Asian immigrants in the U.S., but no diet or physical activity data were available to explain this association (21).

Different religious affiliations within the heterogeneous South Asian community may affect smoking, alcohol use, and dietary practices differentially because of lifestyle prescriptions specific to each religion (22). For example, Hinduism prescribes vegetarianism, Islam prohibits alcohol or pork ingestion, and Sikhism strongly prohibits tobacco use (22-24). As immigrants increase their exposure to Western cultural practices, they may adopt the less healthy food choices found in their host country (25-29). For South Asians, this may mean reduced intake of plant foods and home-cooked meals that may increase risk for overweight/ obesity and related conditions (30-32).

Using data from the Mediators in Arthrosclerosis in South Asians Living in America (MASALA) study which included measures of diet, physical activity, and strength of traditional cultural beliefs, our objective was to examine the associations between religious affiliations and overweight or obese BMI among a religiously heterogeneous group of South Asians.

\section{METHODS}

Participants

The MASALA study is a community-based cohort investigating the prevalence and associations of cardiovascular risk factors and subclinical atherosclerosis in a populationbased sample of South Asian men and women age 40-84 years (33). The MASALA study is the first prospective cohort of U.S. South Asians and was modeled on the Multi-Ethnic Study of Atherosclerosis (MESA) to allow for efficient and valid cross-ethnic comparisons (34). We enrolled 906 South Asians, free of CVD at baseline, from two geographical regions between October 2010 and March 2013.

\section{Data Collection}

Measurements obtained at baseline included (but not limited to) sociodemographics, lifestyle factors, anthropometric measurements, oral glucose tolerance testing, brachial blood pressure, and blood samples for biochemical risk factors. Participants self-reported 
religious affiliation with Hinduism, Sikhism, Islam, Jainism, Christianity, Buddhism, Zoroastrianism, or none. We classified participants who reported Buddhism and Zoroastrianism as "Other" $(\mathrm{n}=6)$ and those who reported more than one affiliation as "Multiple" ( $\mathrm{n}=15)$.

BMI was calculated from measured weight and height (33). Three observations for which BMI was missing were dropped. In multivariate analysis, BMI was dichotomized using Asian BMI cutoffs as healthy (BMI $\left.<23 \mathrm{~kg} / \mathrm{m}^{2}\right)$ or overweight/obese (BMI $\left.\geq 23 \mathrm{~kg} / \mathrm{m}^{2}\right)(35$, 36). We included 7 respondents categorized as underweight $\left(\mathrm{BMI}<18.5 \mathrm{~kg} / \mathrm{m}^{2}\right)$ in the healthy BMI category. Waist and hip circumference were measured using a flexible tape measure according to a standardized protocol by certified staff. We defined South Asian abdominal obesity as obese waist circumference as $280 \mathrm{~cm}$ in women and $290 \mathrm{~cm}$ in men (37) and calculated the waist-to-hip ratio.

We included socio-demographic characteristics, health care access, health status, years of residence in the U.S., strength of traditional cultural beliefs, diet and physical activity as covariates in our analysis. Socio-demographics included age, sex, marital status, educational attainment, and income. Health status was gauged by self-reported health status, which has been shown to be associated with mortality in multiethnic populations (38), and cigarette smoking status. Health insurance status was used as a proxy for health care access. We calculated percentage of lifetime in the U.S. from years lived in the U.S. divided by the respondent's current age. Percentage of lifetime in the U.S. may be a better temporal measure than years lived in the U.S. because the former may better quantify the proportion of lifetime exposure to American cultural practices. Among the 19 U.S.-born respondents, we used current age for years lived in the U.S.

Using data from prior qualitative work in Asian Indians (17), we created a traditional cultural beliefs scale consisting of 7 items. The base question was "How much would you wish these traditions from South Asia would be practiced in America?" The seven items included: performing religious ceremonies; serving sweets at ceremonies; fasting on specific occasions; living in a joint family; having an arranged marriage; eating a staple diet of chapatis, rice, dal, vegetable, and yogurt; using spices for health and healing. The items were scored on a Likert scale with higher scores representing weaker traditional Indian beliefs. We analyzed tertiles of the score ( $<12$ for strongest, 12-17 for moderate, and $\geq 17$ representing weakest traditional beliefs). The Cronbach's alpha for this scale in the current study sample was 0.83 with similar reliability in both men and women.

Diet was assessed through an in-person food group intake using the Study of Health Assessment and Risk in Ethnic Groups (SHARE) South Asian Food Frequency Questionnaire, which was developed and validated in South Asians in Canada, and included items unique to the South Asian diet $(39,40)$. With principal component analysis, we have identified three distinctive dietary patterns; each respondent was assigned a factor score for each dietary pattern identified (41). The three major dietary patterns observed, named after the components with the highest factor loadings in each pattern, were: Animal protein (positive for alcohol, coffee, eggs, fish, pasta, pizza, poultry, red meat, refined grains, vegetable oil; negative for whole grain, low-fat dairy, legumes); Fried snacks, sweets and 
high-fat dairy (positive for added fat, butter/ghee, fried snacks, fruit-juice, high-fat dairy, sugar-sweetened beverages, legumes, potatoes, refined grains, rice, snacks, sweets, whole grains; negative for vegetable oil and nuts); and Fruits, Vegetables, Nuts and Legumes (positive for fruit, fruit juice, legumes, low-fat dairy, vegetable oil, nuts, vegetables, whole grains). Physical activity was assessed using the Typical Week's Physical Activity Questionnaire (42) and reported as MET-minutes of physical activity per week. The "metabolic equivalent of task" (MET) is a ratio widely accepted as a replicable measure of the intensity level of a specific form of physical activity.

\section{Analysis}

We describe the prevalence of baseline characteristics in the total sample. Multivariable logistic regression analyses were performed to estimate the odds of being classified as overweight/obese as a function of religious affiliation, adjusted for socio-demographic characteristics, health care access, health status, and percentage of lifetime in the U.S in Model 1 ( $\mathrm{n}=903$ ). Model 2 was additionally adjusted for intensity of traditional cultural beliefs, dietary pattern, and physical activity $(\mathrm{n}=888)$. We dichotomized marital status, educational level, health status, and health care insurance status. Age, percentage of lifetime in the U.S., and exercise MET-min per week were examined as continuous and categorical variables in the model. While income was not included in the final model ( $\mathrm{n}=26 \mathrm{missing}$ observations), our results with or without income were similar. Missing and refused observations were dropped from our multivariate analyses. In all models, we used "None" or no religious affiliation as the reference category.

Multivariable models were also stratified by strength of traditional cultural beliefs (weak, moderate, strong). We tested for sex-specific interactions with religious affiliation and none were found. We conducted mediation analysis using the Karlson/Holm/Breen logit regression tests to determine if traditional cultural beliefs, dietary pattern, physical activity, smoking status, immigrant status (U.S.-born or foreign-born), and/or educational attainment mediated the relationship between religious affiliation and overweight/obese BMI (43). We tested for sex- and age-specific interactions and none were found. The analysis was completed using STATA/SE (version 12.0, StataCorp, College Station, TX).

\section{RESULTS}

The mean age of South Asians in the MASALA cohort was 55 years; most of the sample was married, well-educated, and insured (Table 1). A significant percentage of respondents had high blood cholesterol (46\%), hypertension (41\%), and/or diabetes (25\%). On average, half of respondents' lives were spent in the U.S. The majority of respondents were affiliated with Hinduism, followed by Sikhism, Islam, Jainism, Christianity, other (Buddhism or Zoroastrianism), and multiple religions. Fifty-eight respondents reported no religious affiliation (6.4\%). The age-adjusted mean BMI was $26 \mathrm{~kg} / \mathrm{m}^{2}$, which did not differ by sex. Seventy-six percent of the sample was overweight/obese. Hindus had a mean BMI of 25.8 $\mathrm{kg} / \mathrm{m}^{2}$, Sikhs $27.2 \mathrm{~kg} / \mathrm{m}^{2}$, Muslims $26.7 \mathrm{~kg} / \mathrm{m}^{2}$, Jains $25.6 \mathrm{~kg} / \mathrm{m}^{2}$, Christians $26.4 \mathrm{~kg} / \mathrm{m}^{2}$, other $22.9 \mathrm{~kg} / \mathrm{m}^{2}$, multiple religions $28.4 \mathrm{~kg} / \mathrm{m}^{2}$, and no religious affiliation $26.1 \mathrm{~kg} / \mathrm{m}^{2}$. The figure shows the BMI categories by each religious affiliation. 
In the multivariable analysis, Hindus had 2.12 greater odds of being overweight/obese than respondents with no religious affiliation (95\% CI: 1.16, 3.89; Table 2). This higher odds was also observed for Sikhs (OR 4.23, 95\% CI: 1.72, 10.38) and Muslims (OR 2.78, 95\% CI: $1.14,6.80)$ compared to those with no religious affiliation in Model 1 . We found no significant associations for Jains, Christians, other or multiple religious affiliation respondents. When we additionally adjusted for traditional cultural values, physical activity, and dietary pattern in Model 2, we found similar increased likelihood for being overweight/ obese among Hindus, Sikhs, and Muslims. The addition of macronutrients or substitution of dietary pattern with macronutrients did not meaningfully change the results. Percentage of lifetime in the U.S. was not significantly associated with BMI in adjusted models.

In order to understand if traditional cultural beliefs moderated the relationship between religious affiliation and overweight/obese BMI, we stratified Model 2 by traditional cultural belief score (weak, moderate, or strong). We found that among those with weak traditional beliefs, Hindus (OR 2.34), Sikhs (OR 9.17), and Jains (OR 6.44) were significantly more likely to be overweight/obese than those with no religious affiliation $(\mathrm{p}<0.05)$. No such effect of religious affiliation was found in stratified models of South Asians with strong or moderate cultural beliefs. Traditional cultural beliefs, dietary pattern, and physical activity were examined as mediators of the relationship between religious affiliation and overweight/ obesity. The proportion of the total effect explained by these three variables in the mediation was $8.9 \%$; traditional cultural beliefs contributed $6.9 \%$, while dietary pattern and physical activity contributed $1.1 \%$ each. Smoking status, educational attainment, and immigrant status were not significant mediators.

\section{DISCUSSION}

Risk of overweight/obese BMI was higher among respondents who affiliated with Hinduism, Sikhism, and Islam compared to those with no religious affiliation. We found minimal mediation in the relationship between religious affiliation and overweight/obesity by traditional cultural beliefs, dietary pattern, and physical activity. Adherence to traditional cultural beliefs, which included questions on diet and religious participation, may provide a deeper understanding of why religious affiliation may impact obesity risk in this population.

Our findings are somewhat consistent with a study that found highly religious South Asian Hindus and Sikhs were more likely to be overweight/obese than those who were less religious (21). In contrast to that study, we also found a significant association of being overweight/obese among Muslim South Asian immigrants living in the U.S. Religion and religiosity have been linked to increased body mass index in other non-South Asian populations $(18,20,44-47)$.

We found that a proxy measure of acculturation, as measured by percentage of lifetime in the U.S., was not associated with risk for overweight/obesity. This finding is consistent with some studies that did not find an association between years in the U.S. or English proficiency with obesity $(21,48)$, though other studies have found a positive association with BMI among Asian American immigrants $(49,50)$ Dietary acculturation, or the adoption of western dietary practices, has been observed among immigrants, and one study among 
Canadian South Asian immigrants found that length of residence was associated with increased consumption of fruits and vegetables and improvement in food preparation (i.e., grilling vs. deep frying), but also increased consumption of convenience foods, red meat, sugar-sweetened beverages, and eating out (51). In the MASALA sample, recent South Asian immigrants ( $<20$ years of residence in the U.S.) were more likely to be categorized as following a Fried Snacks, Sweets and High-fat Dairy diet or Fruits and Vegetables dietary pattern in comparison to long-term resident respondents who were more likely to follow a Western dietary pattern (41). Those with stronger traditional cultural beliefs or limited English proficiency were also more likely to adhere to the Sweets and Refined Grains dietary pattern.

Religious practices around diet, physical activity, and tobacco use may possibly explain risk for increased BMI among Hindus, Sikhs, and Muslims compared to those with no religious affiliation. For example, gatherings centered on religious and/or cultural ceremonies for South Asian immigrants may involve consumption of foods high in refined sugar or saturated fat $(17,23,52)$. Nicotine is an appetite suppressant, and practicing Sikhs may abstain from tobacco use, and possibly increase their risk for increased BMI (53). However, cigarette smoking was low in this population overall. Religious Muslims observe daily prayers, which some regard as daily exercise since it involves change in body position (5456); prayers have not been shown to correlate with physical activity measures or weight changes. Cultural/religious and gender norms have also been shown to be a barrier to physical activity among South Asian women (57). In general, South Asians have reportedly low rates of physical activity, and in our sample, one-third of participants were relatively sedentary (<500 METS/min/week) $(3,58)$.

Our study has several limitations. Given the cross-sectional design, we are unable to draw causal inferences about religious affiliation and BMI. Measures of religiosity, such as adherence to religious tenets or practices, were not measured, and may provide further explanation for the positive association; future questionnaires will include questions on religious participation. Our sample was well-educated, which may limit capturing associations between socioeconomic status, religion, and obesity. However, the sample reflects the South Asian community in the U.S. and their distribution by religious affiliation (33). There may have been inadequate power to detect associations between religious affiliation and BMI status among Jains, Christians, other, and multiple religion groups due to small sample sizes. Some researchers may contest using Asian-specific BMI cut-offs given no mortality differences among Asians at these lower cut-points (59). We conducted sensitivity analysis using different BMI classifications (i.e., BMI $\geq 25 \mathrm{~kg} / \mathrm{m}^{2} \mathrm{vs}$. BMI $<25$ $\mathrm{kg} / \mathrm{m}^{2}$ or BMI $\geq 27.5$ or $30 \mathrm{~kg} / \mathrm{m}^{2}$ vs. BMI $<27.5$ or $30 \mathrm{~kg} / \mathrm{m}^{2}$ or BMI as continuous variable) and our results remained robust. Exclusion of underweight individuals or respondents $>70$ years old did not change our results. While those affiliated with Sikhism had a higher waist circumference compared to those with no religious affiliation ( $\beta=3.6$ in both models; $p<0.05$ ), there was no significant relationship between abdominal obesity and religious affiliation (37).

The links between religion, cultural beliefs and weight in South Asian immigrants appear to be unique among other immigrant groups and deserve further exploration. The religious and 
cultural community may be synonymous for some South Asian groups, and South Asians may derive social support from these communities, which may be responsible for encouraging behaviors that increase overweight/obesity risk (13). Obesity, often considered a lifestyle disease, may be influenced by religion and religious practices. For South Asians, who are at greater risk for obesity-related diseases, such as coronary heart disease and diabetes mellitus, religiously and culturally tailored interventions to promote healthy lifestyle behaviors may be especially critical.

\section{ACKNOWLEDGMENTS AND FUNDING}

The MASALA study was supported by the National Institutes of Health (NIH) Grant R01HL093009 and R01HL120725. N. Bharmal received support from the University of California, Los Angeles, Resource Centers for Minority Aging Research Center for Health Improvement of Minority Elderly (RCMAR/CHIME NIH/NIA Grant Number P30-AG021684) and the Los Angeles Stroke Prevention and Intervention Research Program in Health Disparities (NIH / NINDS 1U54NS081764). W. McCarthy received support from National Institutes of Health grant 1P50HL105188\#6094.

\section{Biography}

Dr. Kanaya is a Professor of Medicine, Epidemiology \& Biostatistics at the University of California, San Francisco. She is the principal investigator of the Mediators of Atherosclerosis in South Asians Living in America (MASALA) Study, and is an expert in cardiovascular disease and diabetes prevention. The MASALA Study is focused on examining sociocultural, behavioral, environmental and biologic risk factors of cardiovascular disease in South Asians.

\section{ABREVIATIONS AND ACRONYMS}

BMI body mass index

MASALA Mediators in Atherosclerosis in South Asians Living in America

U.S. United States

OR odds ratio

CI confidence interval

MESA Multi-Ethnic Study of Atherosclerosis

IRB Institutional Review Board

SHARE Study of Health Assessment and Risk in Ethnic Groups

MET Metabolic Equivalent of Task

\section{REFERENCES}

1. U.S. Census Bureau. The Asian Population: 2010. Mar. 2012 Available from: http:// www.census.gov/prod/cen2010/briefs/c2010br-11.pdf

2. Barnes, P., Adams, P., Powell-Griner, E. Advance data from vital and health statistics; no 394. National Center for Health Statistics; Hyattsville, MD: 2008. Health characteristics of the Asian adult population: United States, 2004-2006. 
3. Joshi P, Islam S, Pais P, Reddy S, Dorairaj P, Kazmi K, et al. Risk factors for early myocardial infarction in South Asians compared with individuals in other countries. JAMA. Jan 17; 2007 297(3):286-94. PubMed PMID: 17227980. Epub 2007/01/18. eng. [PubMed: 17227980]

4. Holland AT, Wong EC, Lauderdale DS, Palaniappan LP. Spectrum of Cardiovascular Diseases in Asian-American Racial/Ethnic Subgroups. Annals of Epidemiology. 2011; 21(8):608-14. [PubMed: 21737048]

5. Karter AJ, Schillinger D, Adams AS, Moffet HH, Liu J, Adler NE, et al. Elevated rates of diabetes in Pacific Islanders and Asian subgroups: The Diabetes Study of Northern California (DISTANCE). Diabetes Care. Mar; 2013 36(3):574-9. PubMed PMID: 23069837. Pubmed Central PMCID: PMC3579366. Epub 2012/10/17. eng. [PubMed: 23069837]

6. Moran AE, Forouzanfar MH, Roth GA, Mensah GA, Ezzati M, Murray CJ, et al. Temporal trends in ischemic heart disease mortality in 21 world regions, 1980 to 2010: the Global Burden of Disease 2010 study. Circulation. Apr 8; 2014 129(14):1483-92. PubMed PMID: 24573352. Epub 2014/02/28. eng. [PubMed: 24573352]

7. Ye J, Rust G, Baltrus P, Daniels E. Cardiovascular Risk Factors among Asian Americans: Results from a National Health Survey. Annals of Epidemiology. 2009; 19(10):718-23. [PubMed: 19560369]

8. Fernandez R, Miranda C, Everett B. Prevalence of obesity among migrant Asian Indians: a systematic review and meta-analysis. International Journal of Evidence Based Healthcare. 2011; 9(4):420-8. [PubMed: 22093390]

9. Daniel M, Wilbur J. Physical Activity Among South Asian Indian Immigrants: An Integrative Review. Public Health Nursing. 2011; 28(5):389-401. [PubMed: 22092422]

10. Ghai NR, Jacobsen SJ, Van Den Eeden SK, Ahmed AT, Haque R, Rhoads GG, et al. A comparison of lifestyle and behavioral cardiovascular disease risk factors between Asian Indian and White non-Hispanic men. Ethn Dis. 2012; 22(2):168-74. Spring. PubMed PMID: 22764638. Epub 2012/07/07. eng. [PubMed: 22764638]

11. Misra A, Khurana L. Obesity-related non-communicable diseases: South Asians vs White Caucasians. International journal of obesity (2005). Feb; 2011 35(2):167-87. PubMed PMID: 20644557. Epub 2010/07/21. eng. [PubMed: 20644557]

12. Fekete, EM., Williams, SL. Chronic Disease. In: Loue, S., Sajatovic, M., editors. Encyclopedia of immigrant health. Springer Publishing; New York, NY: 2012.

13. Pollard TM, Carlin LE, Bhopal R, Unwin N, White M, Fischbacher C. Social networks and coronary heart disease risk factors in South Asians and Europeans in the UK. Ethn Health. Aug; 2003 8(3):263-75. PubMed PMID: 14577999. Epub 2003/10/28. eng. [PubMed: 14577999]

14. Basch, L., Schiller, NG., Blanc, CS. Nations Unbound: Transnational Projects. Gordon and Breach; Amsterdam: 1994.

15. Kim, I. The Koreans: small business in an urban frontier. In: Foner, N., editor. New Immigrants in New York. Columbia University Press; New York: 1987.

16. Zhou, M. Chinatown: the socioeconomic potential of an urban enclave. Temple University Press; Philadelphia: 1992.

17. Mukherjea A, Underwood KC, Stewart AL, Ivey SL, Kanaya AM. Asian Indian views on diet and health in the United States: importance of understanding cultural and social factors to address disparities. Family \& community health. Oct-Dec;2013 36(4):311-23. PubMed PMID: 23986072. Pubmed Central PMCID: 3987985. Epub 2013/08/30. eng. [PubMed: 23986072]

18. Feinstein M, Liu K, Ning H, Fitchett G, Lloyd-Jones DM. Burden of cardiovascular risk factors, subclinical atherosclerosis, and incident cardiovascular events across dimensions of religiosity: The multi-ethnic study of atherosclerosis. Circulation. Feb 9; 2010 121(5):659-66. PubMed PMID: 20100975. Pubmed Central PMCID: 2871276. Epub 2010/01/27. eng. [PubMed: 20100975]

19. Feinstein M, Liu K, Ning H, Fitchett G, Lloyd-Jones DM. Incident obesity and cardiovascular risk factors between young adulthood and middle age by religious involvement: The Coronary Artery Risk Development in Young Adults (CARDIA) Study. Preventive Medicine. Feb 1; 2012 54(2): 117-21. [PubMed: 22155479] 
20. Gillum RF. Frequency of attendance at religious services, overweight, and obesity in American women and men: the Third National Health and Nutrition Examination Survey. Ann Epidemiol. Sep; 2006 16(9):655-60. PubMed PMID: 16431132. Epub 2006/01/25. eng. [PubMed: 16431132]

21. Bharmal N, R MK, Shapiro MF, Kagawa-Singer M, Wong MD, Mangione CM, et al. The association of religiosity with overweight/obese body mass index among Asian Indian immigrants in California. Prev Med. Oct; 2013 57(4):315-21. PubMed PMID: 23769898. Epub 2013/06/19. eng. [PubMed: 23769898]

22. Eliasi JR, Dwyer JT. Kosher and Halal: Religious observances affecting dietary intakes. J Am Diet Assoc. Jul; 2002 102(7):911-3. PubMed PMID: ISI:000176711200005. [PubMed: 12146548]

23. Jonnalagadda SS, Diwan S. Regional variations in dietary intake and body mass index of firstgeneration Asian-Indian immigrants in the United States. J Am Diet Assoc. Sep; 2002 102(9): 1286-9. PubMed PMID: 12792628. Epub 2003/06/07. eng. [PubMed: 12792628]

24. Raymond C, Sukhwant BAL. The drinking habits of Sikh, Hindu, Muslim and white men in the West Midlands: a community survey. Addiction. 1990; 85(6):759-69.

25. Akresh IR. Dietary Assimilation and Health among Hispanic Immigrants to the United States. Journal of health and social behavior. 2007; 48(4):404-17. [PubMed: 18198687]

26. Batis C, Hernandez-Barrera L, Barquera S, Rivera JA, Popkin BM. Food Acculturation Drives Dietary Differences among Mexicans, Mexican Americans, and Non-Hispanic Whites. The Journal of Nutrition. Oct 1; 2011 141(10)::1898-906. 2011. [PubMed: 21880951]

27. Guendelman MD, Cheryan S, Monin B. Fitting In but Getting Fat: Identity Threat and Dietary Choices Among U.S. Immigrant Groups. Psychological Science. Jul 1; 2011 22(7):959-67. [PubMed: 21653909]

28. Kim MJ, Lee SJ, Ahn YH, Bowen P, Lee H. Dietary acculturation and diet quality of hypertensive Korean Americans. Journal of advanced nursing. 2007; 58(5):436-45. [PubMed: 17442024]

29. Lv N, Cason KL. Dietary pattern change and acculturation of Chinese Americans in Pennsylvania. J Am Diet Assoc. May; 2004 104(5):771-8. PubMed PMID: 15127063. Epub 2004/05/06. eng. [PubMed: 15127063]

30. Raj S, Ganganna P, Bowering J. Dietary habits of Asian Indians in relation to length of residence in the United States. J Am Diet Assoc. Sep; 1999 99(9):1106-8. PubMed PMID: 10491683. Epub 1999/09/24. eng. [PubMed: 10491683]

31. Karim N, Bloch DS, Falciglia G, Murthy L. Modifications in food consumption patterns reported by people from India, living in Cincinnati, Ohio. Ecology Of Food And Nutrition. 1986; 19(1):118.

32. Garduno-Diaz SD, Khokhar S. South Asian dietary patterns and their association with risk factors for the metabolic syndrome. Journal of human nutrition and dietetics : the official journal of the British Dietetic Association. Apr; 2013 26(2):145-55. PubMed PMID: 22943473. Epub 2012/09/05. eng.

33. Kanaya AM, Kandula N, Herrington D, Budoff MJ, Hulley S, Vittinghoff E, et al. Mediators of Atherosclerosis in South Asians Living in America (MASALA) Study: Objectives, Methods, and Cohort Description. Clinical Cardiology. 2013; 36(12):713-20. [PubMed: 24194499]

34. Bild DE, Bluemke DA, Burke GL, Detrano R, Diez Roux AV, Folsom AR, et al. Multi-ethnic study of atherosclerosis: objectives and design. American journal of epidemiology. Nov 1; 2002 156(9): 871-81. PubMed PMID: 12397006. Epub 2002/10/25. eng. [PubMed: 12397006]

35. World Health Organization expert consultation. Appropriate body-mass index for Asian populations and its implications for policy and intervention strategies. Lancet. Jan 10; 2004 363(9403):157-63. PubMed PMID: ISI:000187939200021. [PubMed: 14726171]

36. Jih J, Mukherjea A, Vittinghoff E, Nguyen TT, Tsoh JY, Fukuoka Y, et al. Using appropriate body mass index cut points for overweight and obesity among Asian Americans. Prev Med. Apr 13.2014 65C:1-6. PubMed PMID: 24736092. Epub 2014/04/17. Eng.

37. Alberti KGMM, Zimmet P, Shaw J. Metabolic syndrome-a new world-wide definition. A Consensus Statement from the International Diabetes Federation. Diabetic Medicine. 2006; 23(5): 469-80. [PubMed: 16681555]

38. McGee DL, Liao Y, Cao G, Cooper RS. Self-reported health status and mortality in a multiethnic US cohort. American journal of epidemiology. 1999; 149(1):41-6. [PubMed: 9883792] 
39. Kelemen LE, Anand SS, Vuksan V, Yi Q, Teo KK, Devanesen S, et al. Development and evaluation of cultural food frequency questionnaires for South Asians, Chinese, and Europeans in North America. J Am Diet Assoc. 2003; 103(9):1178-84. [PubMed: 12963948]

40. Wang ET, de Koning L, Kanaya AM. Higher protein intake is associated with diabetes risk in south asian indians: the Metabolic Syndrome and Atherosclerosis in South Asians Living in America (MASALA) study. J Am Coll Nutr. Apr; 2010 29(2):130-5. PubMed PMID: 20679148. Epub 2010/08/04. eng. [PubMed: 20679148]

41. Gadgil MD, Anderson CAM, Kandula NR, Kanaya AM. Dietary Patterns and Associations with Metabolic Risk Factors in South Asians. Diabetes. Jun; 2014 63(Supplement 1):A343-A425.

42. Ainsworth BE, Haskell WL, Herrmann SD, Meckes N, Bassett DR Jr, Tudor-Locke C, et al. 2011 Compendium of Physical Activities: a second update of codes and MET values. Med Sci Sports Exerc. Aug; 2011 43(8):1575-81. PubMed PMID: 21681120. Epub 2011/06/18. eng. [PubMed: 21681120]

43. Karlson KB, Holm A. Decomposing primary and secondary effects: A new decomposition method. Research in Social Stratification and Mobility. 2011; 29(2):221-37.

44. Cline KMC, Ferraro KF. Does religion increase the prevalence and incidence of obesity in adulthood? J Sci Stud Relig. Jun; 2006 45(2):269-81. PubMed PMID: ISI:000238044000009.

45. Ferraro KF. Firm Believers? Religion, Body Weight, and Well-Being. Review of Religious Research. 1998; 39(3):224-44.

46. Lapane KL, Lasater TM, Allan C, Carleton RA. Religion and cardiovascular disease risk. Journal of Religion and Health. 1997; 36(2):155-64.

47. Kim KH, Sobal J, Wethington E. Religion and body weight. Int J Obes Relat Metab Disord. Apr; 2003 27(4):469-77. PubMed PMID: 12664080. Epub 2003/03/29. eng. [PubMed: 12664080]

48. Nguyen HH, Smith C, Reynolds GL, Freshman B. The Effect of Acculturation on Obesity Among Foreign-Born Asians Residing in the United States. J Immigr Minor Health. Apr.2014 30 PubMed PMID: 24781781. Epub 2014/05/02. Eng.

49. Chen L, Juon HS, Lee S. Acculturation and BMI among Chinese, Korean and Vietnamese adults. J Community Health. Jun; 2012 37(3):539-46. PubMed PMID: 21922164. Pubmed Central PMCID: PMC3804273. Epub 2011/09/17. eng. [PubMed: 21922164]

50. Lauderdale DS, Rathouz PJ. Body mass index in a US national sample of Asian Americans: effects of nativity, years since immigration and socioeconomic status. Int J Obes Relat Metab Disord. Sep; 2000 24(9):1188-94. PubMed PMID: 11033989. Epub 2000/10/18. eng. [PubMed: 11033989]

51. Lesser IA, Gasevic D, Lear SA. The association between acculturation and dietary patterns of South Asian immigrants. PloS one. 2014; 9(2):e88495. PubMed PMID: 24558396. Pubmed Central PMCID: 3928252. Epub 2014/02/22. eng. [PubMed: 24558396]

52. Deedwania P, Singh V. Coronary artery disease in South Asians: evolving strategies for treatment and prevention. Indian Heart J. Nov-Dec;2005 57(6):617-31. PubMed PMID: 16521627. Epub 2006/03/09. eng. [PubMed: 16521627]

53. Flegal KM, Troiano RP, Pamuk ER, Kuczmarski RJ, Campbell SM. The influence of smoking cessation on the prevalence of overweight in the United States. N Engl J Med. Nov 2; 1995 333(18):1165-70. PubMed PMID: 7565970. Epub 1995/11/02. eng. [PubMed: 7565970]

54. Reza MF, Urakami Y, Mano Y. Evaluation of a new Physical Exercise Taken from Salat (Prayer) as a Short-Duration and Frequent Physical Activity in the Rehabilitation of Geriatric and Disabled Patients. Annals of Saudi Medicine. 2002; 22(3/4):177-80. [PubMed: 17159390]

55. Tirodkar MA, Baker DW, Makoul GT, Khurana N, Paracha MW, Kandula NR. Explanatory Models of Health and Disease Among South Asian Immigrants in Chicago. J Immigr Minor Health. Apr; 2011 13(2):385-94. PubMed PMID: 20131000. Pubmed Central PMCID: 2905487. Eng. [PubMed: 20131000]

56. Greenhalgh T, Helman C, Chowdhury AMm. Health beliefs and folk models of diabetes in British Bangladeshis: a qualitative study. BMJ. Mar; 1998 316(7136):978-83. [PubMed: 9550958]

57. Dave SS, Craft LL, Mehta P, Naval S, Kumar S, Kandula NR. Life Stage Influences on U.S. South Asian Women's Physical Activity. American journal of health promotion : AJHP. Apr 9.2014 PubMed PMID: 24717067. Epub 2014/04/11. Eng. 
58. US Department of Health and Human Services. Physical activity guidelines for Americans 2008. Available from: http://www.health.gov/paguidelines/guidelines/chapter1.aspx

59. Zheng W, McLerran DF, Rolland B, Zhang X, Inoue M, Matsuo K, et al. Association between Body-Mass Index and Risk of Death in More Than 1 Million Asians. New England Journal of Medicine. 2011; 364(8):719-29. [PubMed: 21345101] 


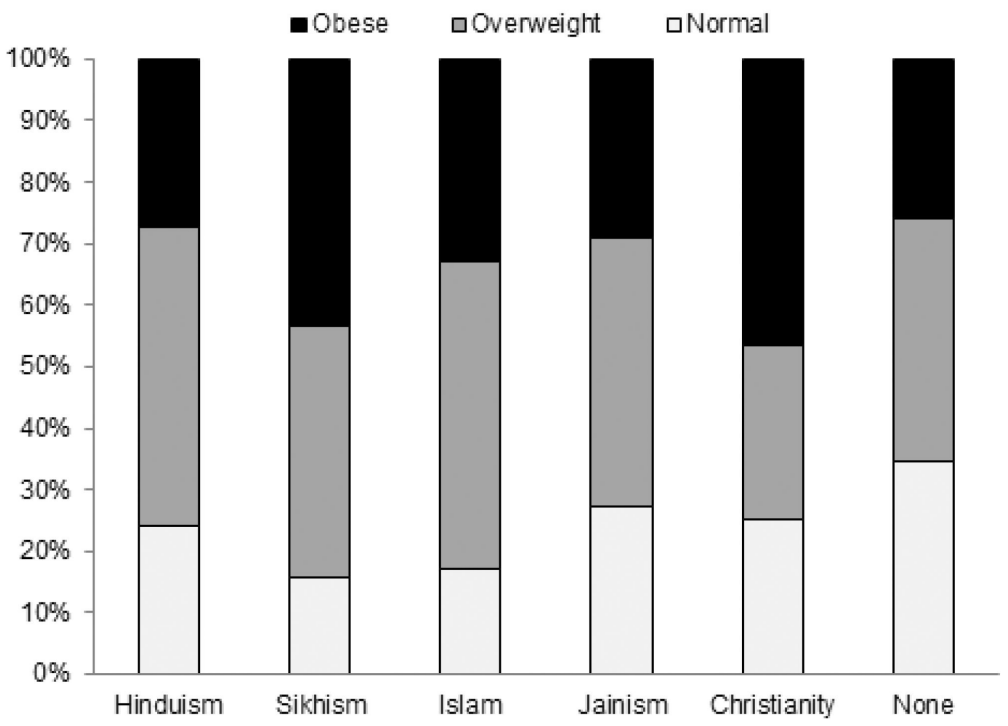

Figure.

BMI category by religious affiliation in MASALA (Normal BMI $<23 \mathrm{~kg} / \mathrm{m}^{2}$; overweight $23-27.5 \mathrm{~kg} / \mathrm{m}^{2}$; obese $>27.5 \mathrm{~kg} / \mathrm{m}^{2}$ ) 


\section{Table 1}

Characteristics of South Asians in MASALA baseline examination, 2010-2013, $n=906^{a}$

\begin{tabular}{|c|c|c|}
\hline Characteristic & $\mathrm{N}=906$ & $\%$ or mean $(\mathrm{SD})$ \\
\hline Age (years) & & $55.3(9.4)$ \\
\hline $39-49 y(\%)$ & 293 & 32.3 \\
\hline $50-59 y(\%)$ & 302 & 33.3 \\
\hline $60-69 y(\%)$ & 235 & 25.9 \\
\hline $70-83 y(\%)$ & 76 & 8.4 \\
\hline \multicolumn{3}{|l|}{$\operatorname{Sex}(\%)$} \\
\hline Male & 486 & 53.6 \\
\hline Female & 420 & 46.4 \\
\hline \multicolumn{3}{|l|}{ Marital status (\%) } \\
\hline Married & 822 & 90.7 \\
\hline Not married & 84 & 9.3 \\
\hline \multicolumn{3}{|l|}{ Educational attainment (\%) } \\
\hline$<$ Bachelor's degree & 110 & 12.1 \\
\hline ¿Bachelor's degree & 796 & 87.9 \\
\hline \multicolumn{3}{|c|}{ Annual household income (\%) } \\
\hline$<\$ 100,000$ & 324 & 36.8 \\
\hline$\geq \$ 100,000$ & 556 & 63.2 \\
\hline \multicolumn{3}{|l|}{ Health insurance (\%) } \\
\hline Insured & 828 & 91.4 \\
\hline Not insured & 78 & 8.5 \\
\hline \multicolumn{3}{|l|}{ Health status (\%) } \\
\hline Poor/fair/good & 162 & 17.9 \\
\hline Very good/excellent & 744 & 82.1 \\
\hline \multicolumn{3}{|l|}{ Health conditions (\%) } \\
\hline High blood cholesterol & 404 & 45.7 \\
\hline Hypertension & 370 & 40.8 \\
\hline Diabetes & 230 & 25.6 \\
\hline \multicolumn{3}{|l|}{ Smoking status (\%) } \\
\hline Never & 751 & 82.9 \\
\hline Former & 124 & 13.7 \\
\hline Current & 31 & 3.4 \\
\hline \multicolumn{3}{|c|}{ Alcohol use $(1+$ drinks/week $)(\%)$} \\
\hline Yes & 299 & 33.0 \\
\hline No & 607 & 67.0 \\
\hline \multicolumn{3}{|c|}{ Exercise MET/min/week categories (\%) } \\
\hline $0-499$ & 295 & 32.6 \\
\hline $500-999$ & 180 & 19.9 \\
\hline 1000-1999 & 225 & 24.8 \\
\hline $2000+$ & 206 & 22.7 \\
\hline
\end{tabular}




\begin{tabular}{|c|c|c|}
\hline Characteristic & $\mathrm{N}=906$ & $\%$ or mean $(\mathrm{SD})$ \\
\hline \multicolumn{3}{|l|}{ Dietary Pattern (\%) } \\
\hline Animal protein & 298 & 33.4 \\
\hline Fried snacks/sweets/high-fat dairy & 304 & 34.1 \\
\hline Fruits/vegetables/nuts/legumes & 290 & 32.5 \\
\hline Percentage of lifetime in U.S. & 906 & $50.5(18.0)$ \\
\hline \multicolumn{3}{|l|}{ Traditional South Asian beliefs score (\%) } \\
\hline Strong $(0-11)(\%)$ & 300 & 33.2 \\
\hline Moderate (12-16) (\%) & 323 & 35.7 \\
\hline Weak $(17-28)(\%)$ & 281 & 31.1 \\
\hline \multicolumn{3}{|l|}{ Religious affiliation (\%) } \\
\hline Hinduism & 610 & 67.3 \\
\hline Sikhism & 69 & 7.6 \\
\hline Islam & 64 & 7.1 \\
\hline Jainism & 56 & 6.2 \\
\hline Christianity & 28 & 3.1 \\
\hline Other (Buddhism, Zoroastrianism) & 6 & 0.7 \\
\hline Multiple religions & 15 & 1.7 \\
\hline None & 58 & 6.4 \\
\hline Body mass index $\left(\mathrm{kg} / \mathrm{m}^{2}\right)$ & 903 & $26.0(4.3)$ \\
\hline Underweight (BMI < 18.5) $(\%)$ & 7 & 0.8 \\
\hline Normal $(18.5 \leq \mathrm{BMI}<23)(\%)$ & 210 & 23.6 \\
\hline Overweight $(23 \leq \mathrm{BMI}<27.5)(\%)$ & 415 & 46.0 \\
\hline Obese (BMI $\geq 27.5)(\%)$ & 271 & 30.0 \\
\hline Waist circumference $(\mathrm{cm})$ & 905 & $92.8(10.3)$ \\
\hline \multicolumn{3}{|l|}{ Obese waist $\mathrm{cm}(\%)$} \\
\hline ( $280 \mathrm{~cm}$ women; $\searrow 90 \mathrm{~cm}$ men) & 905 & 78.3 \\
\hline Waist to hip ratio & 905 & $0.90(0.07)$ \\
\hline
\end{tabular}

${ }^{a}$ Column totals may not sum to $100 \%$ due to rounding error or missing observations. 


\section{Table 2}

Adjusted odds ratios examining overweight/obesity status by religious affiliation among South Asians, MASALA baseline examination, 2010-2013 ${ }^{a}$

\begin{tabular}{|c|c|c|c|}
\hline & Unadjusted, $n=903(95 \%$ CI $)$ & Model 1, n=903 (95\% CI) & Model 2, $\mathrm{n}=\mathbf{8 8 8}(\mathbf{9 5 \%} \mathrm{CI})$ \\
\hline \multicolumn{4}{|l|}{ Religious affiliation } \\
\hline None & 1.00 & 1.00 & 1.00 \\
\hline Hinduism & $1.65(0.93,2.93)$ & $1.95(1.07,3.53)$ & $2.02(1.08,3.80)$ \\
\hline Sikhism & $2.78(1.20,6.44)$ & $3.48(1.46,8.33)$ & $3.61(1.46,8.89)$ \\
\hline Islam & $2.54(1.09,5.91)$ & $2.54(1.05,6.17)$ & $2.61(1.01,6.73)$ \\
\hline Jainism & $1.40(0.63,3.13)$ & $1.74(0.76,3.96)$ & $1.87(0.78,4.46)$ \\
\hline Christianity & $1.58(0.57,4.35)$ & $1.69(0.60,4.78)$ & $1.68(0.58,4.88)$ \\
\hline Other (Buddhism, Zoroastrianism) & $0.26(0.04,1.56)$ & $0.30(0.05,1.83)$ & $0.41(0.07,2.52)$ \\
\hline Multiple religions & $3.42(0.70,16.68)$ & $4.17(0.83,20.81)$ & $4.51(0.89,22.74)$ \\
\hline Percentage lifetime U.S. & & $1.00(0.99,1.00)$ & $0.99(0.98,1.00)$ \\
\hline \multicolumn{4}{|l|}{ Age categories } \\
\hline $39-49 y$ & & 1.00 & 1.00 \\
\hline $50-59 y$ & & $0.82(0.55,1.22)$ & $0.83(0.55,1.25)$ \\
\hline $60-69 y$ & & $0.69(0.45,1.06)$ & $0.69(0.45,1.06)$ \\
\hline $70-83 y$ & & $0.47(0.26,0.85)$ & $0.48(0.26,0.87)$ \\
\hline \multicolumn{4}{|l|}{$\operatorname{Sex}$} \\
\hline Male & & 1.00 & 1.00 \\
\hline Female & & $1.04(0.74,1.47)$ & $1.04(0.73,1.47)$ \\
\hline \multicolumn{4}{|l|}{ Marital Status } \\
\hline Not married & & 1.00 & 1.00 \\
\hline Married & & $0.59(0.32,1.09)$ & $0.58(0.31,1.08)$ \\
\hline \multicolumn{4}{|l|}{ Educational attainment } \\
\hline$<$ Bachelor's degree & & 1.00 & 1.00 \\
\hline$\geq$ Bachelor's degree & & $0.93(0.55,1.58)$ & $1.00(0.58,1.73)$ \\
\hline \multicolumn{4}{|l|}{ Health insurance } \\
\hline Not insured & & 1.00 & 1.00 \\
\hline Insured & & $0.70(0.36,1.35)$ & $0.78(0.39,1.58)$ \\
\hline \multicolumn{4}{|l|}{ Health status } \\
\hline Poor/fair/good & & 1.00 & 1.00 \\
\hline Very good/excellent & & $0.90(0.59,1.37)$ & $0.93(0.61,1.44)$ \\
\hline \multicolumn{4}{|l|}{ Smoking status } \\
\hline Never & & 1.00 & 1.00 \\
\hline Former & & $1.41(0.86,2.31)$ & $1.44(0.86,2.40)$ \\
\hline Current & & $1.53(0.56,4.19)$ & $1.80(0.59,5.48)$ \\
\hline \multicolumn{4}{|l|}{ Cultural beliefs } \\
\hline Strong & & & 1.00 \\
\hline Moderate & & & $0.71(0.47,1.05)$ \\
\hline
\end{tabular}

J Relig Health. Author manuscript; available in PMC 2019 February 01. 


\begin{tabular}{|c|c|c|c|}
\hline & Unadjusted, $\mathrm{n}=903$ (95\% CI) & Model 1, n=903 (95\% CI) & Model 2, n=888 $(95 \%$ CI $)$ \\
\hline Weak & & & $0.86(0.55,1.34)$ \\
\hline \multicolumn{4}{|c|}{ Exercise (MET/min/week) } \\
\hline $0-499$ & & & 1.00 \\
\hline $500-999$ & & & $0.62(0.39,0.98)$ \\
\hline $1000-1999$ & & & $0.82(0.52,1.30)$ \\
\hline $2000+$ & & & $0.69(0.44,1.10)$ \\
\hline \multicolumn{4}{|l|}{ Dietary Pattern } \\
\hline Animal protein & & & 1.00 \\
\hline Fried snacks/ Sweets & & & $1.23(0.80,1.91)$ \\
\hline Fruits \& Vegetables & & & $1.08(0.70,1.65)$ \\
\hline
\end{tabular}

${ }^{a}$ Bold font when $\mathrm{p}<0.05$ 